\title{
METODE PENYEMBUHAN PENDERITA SKIZOFRENIA OLEH MANTRI DALAM PERSPEKTIF PEKERJAAN SOSIAL
}

\author{
Pairan, Akhmad Munif Mubarok, Ekananda Novianta Nugraha \\ Universitas Jember (UNEJ) \\ Jl. Kalimantan X, No. 01, Jember 68121 \\ Email: pakpe99@yahoo.com
}

Received: $2^{\text {th }}$ March 2018; Revised: $30^{\text {th }}$ April 2018; Accepted: $19^{\text {th }}$ June 2018

\begin{abstract}
This research aimed to know the mantri's healing methods of schizophrenia patients in social work perspective in Andongsari Hamlet of Tugusari Village. The research problem was how the effort of professional nurse in the healing process of schizophrenia patients. The limited cost for treatment and creating negative stigma of public about schizophrenia made schizophrenia patients undergo the unfeasible treatment. With the existence of this professional nurse effort could help lighten up the families and schizophrenia patients in the healing process of schizophrenia. This research used qualitative research method with case study research type. The research location was conducted in Andongsari Hamlet, Tugusari Village, Bangsalsari Sub-district, Jember Regency. The research result was the professional nurse could help patients of schizophrenia in the healing process by utilizing the source system as support in the healing effort of schizophrenia patients. The treatment method that was done by the nurse to the schizophrenia patients through therapic medical, by providing medical medicine to make reimprovement of social function of that schizophrenia patients. Therapic stages of social function through a series activities: (a) family understanding of cognitive disability. (b) introduction of schizophrenia to environment; (c) digging the potency of the schizophrenia patients.
\end{abstract}

Keywords: healing method, schizophrenia, healing process, mantri, social function.

Abstrak. Penelitian ini ditujukan untuk memahami pengobatan mantri pada pasien penderita skizofrenia dalam perspektif kerja sosial di Dusun Kecil Andongsari, Desa Tugusari. Masalah penelitian ini adalah bagaimana upaya perawatan profesional dalam proses pengobatan atas pasien penderita skizofrenia. Terbatasnya penghargaan perlakuan dan penciptaan stigma negatif publik pada skizofrenia dapat membuat pasien penderita skizofrenia mengalami perlakuan yang tidak layak. Dengan upaya perawatan secara profesional ini dapat membantu mengurangi kekhawatiran keluarga dan pasien penderita skizofrenia dalam proses pengobatan skizofrenia. Penelitian ini menggunakan metode penelitian kualitatif dengan tipe studi kasus. Lokasi penelitian dilakukan di Dusun Andongsari, Desa Tugasari, Kecamatan Bangsalsari, Kabupaten Jember. Hasil penelitian ini adalah perawatan profesional dapat membantu pasien skizofrenia dalam proses penyembuhannya dengan menggunakan sistem sumber daya sebagai dukungan dalam upaya penyembuhan pasien skizofrenia. Metode perlakuan yang dilakukan dalam pengobatan atas penderita skizofrenia ini melalui terapi medis yakni dengan menyediakan obat medis untuk mengembalikan keberfungsian sosial dari pasien penderita skizofrenia. Tahapan terapi fungsi sosial melewati beberapa aktifitas: (a) pemahaman keluarga atas disabilitas kognitif; (b) pengenalan skizofrenia pada lingkungan; (c) penggalian potensi penderita skizofrenia.

Kata Kunci: metode pengobatan, skizofrenia, proses pengobatan, mantri, fungsi sosial. 


\section{Pendahuluan}

Skizofrenia telah dikenal sejak satu abad yang lalu dan merupakan salah satu penyakit medis yang menyerang mental penderita. Skizofrenia adalah gangguan jiwa psikotik yang menimbulkan gejala kejiwaan, seperti kekacauan dalam berpikir, emosi, persepsi, dan perilaku menyimpang, dengan gejala utama berupa waham (keyakinan salah), delusi (pandangan yang tidak benar), dan halusinasi (persepsi tanpa ada rangsang pancaindra).

Skizofrenia merupakan penyakit yang mudah kambuh dan bisa menetap dalam jangka waktu yang cukup panjang. Bisa saja penyakit ini menetap pada penderita seumur hidupnya. Bila dibiarkan, penyakit ini dapat mengakibatkan kemunduran dalam berbagai aspek kehidupan sosial penderita. Meski serius, penyakit ini dapat disembuhkan, terutama bila diobati dengan sungguh-sungguh. Ada berbagai cara pendekatan dalam pengobatan skizofrenia. Semua pendekatan dan pengobatan skizofrenia tergantung dari kebutuhan penderita, karena setiap penderita memiliki pengobatan yang berbeda sesuai dengan jenis skizofrenia yang dideritanya. (Fausiah dan Widury, 2006).

Menurut data World Health Organization (WHO) 2013, skizofrenia merupakan gangguan mental yang berat. Pada saat ini, penderita skizofrenia jumlahnya mengalami peningkatan terkait dengan berbagai macam permasalahan yang dialami, mulai dari kondisi perekonomian yang memburuk, kondisi keluarga atau latar belakang pola asuh anak yang tidak baik sampai bencana alam yang melanda. WHO juga menyebutkan pada tahun 2013 jumlah penderita skizofrenia mencapai 450 juta jiwa di seluruh dunia.

Irmansyah dalam Yosep dan Sutini (2014) menyebutkan bahwa 7 dari 1000 orang di dunia menderita skizofrenia. Saat ini, jumlah penderita skizofrenia mencapai 24.000.000 orang di seluruh dunia. Prevalensi skizofrenia pada masyarakat umum sebesar 0,2-0,8\% dan timbul sekitar usia 18 sampai 45 tahun. Skizofrenia menyerang semua kelompok masyarakat tanpa pandang bulu. Pria-wanita, kaya-miskin, ras BaratTimur, pendidikan tinggi-rendah mempunyai resiko yang sama untuk menderita skizofrenia.

Bagi keluarga penderita yang memiliki ekonomi menengah ke bawah lebih memilih untuk memasung anggota keluarga yang menderita skizofrenia karena tidak sanggup untuk berobat ke rumah sakit. Belum lagi kepercayaan tinggi akan hal mistis membuat para penderita skizofrenia dianggap terkutuk, kerasukan makhluk gaib, akibat diguna-guna atau akibat masalah spiritual. Pemasungan terjadi karena bermacammacam alasan, sebagian masyarakat memiliki pemahaman dan pengetahuan yang 
salah tentang gangguan jiwa (skizofrenia). Penderita skizofrenia dianggap berbahaya bagi lingkungannya, pemasungan dianggap sebagai solusi untuk mengendalikan gejala kerasukan, atau mengurangi ulah penderita skizofrenia.

Desa Tugusari, Kecamatan Bangsalsari, merupakan wilayah yang ada di Kabupaten Jember yang diketahui memiliki 6 orang penderita skizofrenia, jumlah tersebut merupakan jumlah terbanyak jika dibandingkan dengan Kecamatan atau Desa lainnya yang ada di Kabupaten Jember (BD, petugas dinas sosial. September 2016). Sebagai upaya dalam menanggulangannya, diketahui bahwa telah terdapat terdapat mantri yang bertugas khusus untuk membantu dalam proses penyembuhan penderita skizofrenia tersebut.

Merujuk pada pengakuan masyarakat dinyatakan bahwa mantri yang bertugas terbilang sangat aktif dalam menjalankan tugasnya. Namun yang disayangkan keaktifan mantri masih belum mampu ditunjang dengan baik oleh pihak keluarga penderita, sehingga mantri hanya bisa menangani 2 orang dari 6 orang jumlah penderita skizofrenia yang ada di desa. Hal tersebut terjadi karena masyarakat sudah terlanjur mempercayai bahwa penyakit skizofrenia dianggap berbahaya dan tidak bisa disembuhkan. Sehingga upaya untuk menyembuhkan merupakan suatu hal yang dianggap percuma.

Berdasar temuan lapangan diketahui bahwa sebagian besar masyarakat masih berpandangan bahwa memiliki anggota keluarga penderita skizofrenia merupakan aib, sehingga anggota keluarga cenderung menyembunyikan bahkan memasungnya dengan cara-cara yang kurang manusiawi dengan berbagai alasan yang cenderung apologi. Sebagai dampaknya, kondisi penderita skizofrenia bukan justru semakin membaik.

Padahal jika merujuk pada Peraturan Pemerintah Republik Indonesia Nomor 36 Tahun 1980 tentang Usaha Kesejahteraan Sosial bagi penderita cacat, dinyatakan bahwa "rehabilitasi adalah suatu proses refungsionalisasi dan pengembangan untuk memungkinkan penderita cacat mampu melaksanakan fungsi sosialnya secara wajar dalam kehidupan masyarakat" (pasal 1 ayat 2) dengan tujuan mengembalikan individu menjadi warga yang produktif, memiliki peranan dan dapat berinteraksi dengan masyarakat di lingkungannya.

Selain itu, dalam Undang-Undang No 39 Tahun 1999 tentang Hak Asasi Manusia pasal 42 juga dinyatakan bahwa "setiap warga negara yang berusia lanjut, cacat fisik dan atau cacat mental berhak mendapatkan perawatan, pendidikan, pelatihan dan bantuan khusus atas biaya negara untuk menjamin kehidupan yang layak sesuai dengan martabat kemanusiaannya, meningkatkan rasa percaya diri dan kemampuan 
beradaptasi dalam kehidupan bermasyarakat, berbangsa dan bernegara". Jika merujuk pada peraturan pemerintah dan undang-undang di atas, artinya penanganan pada penderita skizofrenia sangat penting untuk dilakukan, karena hal tersebut merupakan hak dan juga akan memberi dampak pada penyembuhan penderita nantinya.

Dalam ilmu kesejahteraan sosial, penderita skizofrenia dapat dikategorikan sebagai Penyandang Masalah Kesejahteraan Sosial (PMKS), karena hal yang dialami merupakan suatu hambatan, kesulitan atau gangguan, yang menyebabkan tidak terlaksananya fungsi sosial penderita, dan karenanya juga penderita tidak mampu menjalin hubungan yang serasi dan kreatif dengan lingkungannya sehingga tidak dapat terpenuhi kebutuhan hidupnya (jasmani, rohani dan sosial) secara memadai dan wajar.

Penanganan yang dilakukan sebagai upaya dalam proses penyembuhan penderita skizofrenia di Desa Tugusari, mantri melakukannya dengan menggunakan berbagai metode sebagai upayanya. Metode tersebut tidak hanya dilakukan untuk menyembuhkan saja namun juga dilakukan untuk pengembalian keberfungsian sosial penderita skizofrenia.

Berdasar pada hasil observasi, diketahui bahwa selain menggunakan pendekatan medis, mantri juga telah berkolaborasi dengan petugas dari dinas sosial untuk melakukan pendekatan pada keluarga dan masyarakat sebagai metode pekerjaan sosial dalam proses penyembuhan penderita skizofrenia. Di dalam metode pekerjaan sosial tersebut, keluarga dan masyarakat dapat dikatakan sebagai lingkungan terdekat yang mampu menstimulasi secara positif atau negatif pada kesembuhan penderita skizofrenia. Mantri juga menekankan pada keberfungsian sosial dalam proses penyembuhannya. Hal tersebut sejalan dengan apa yang dikatakan oleh Edi Suharto (2009) bahwa keberfungsian sosial sebagai kemampuan orang (Individu, keluarga, kelompok atau masyarakat) dan sistem sosial (lembaga, dan jaringan sosial) dalam memenuhi atau merespon kebutuhan dasar, menjalankan peranan sosial, serta menghadapi goncangan dan tekanan (shocks and stresses).

Hilangnya gejala skizofrenia pada seseorang tidak menjamin kesembuhan, karena dikatakan sembuh atau normal kembali apabila seseorang telah mampu memenuhi kebutuhan dasarnya, mampu menjalakan peranan sosialnya, dan mampu menghadapi goncangan serta tekanan yang dihadapinya. Oleh karena itu, dalam proses penyembuhan atas penderita skizofrenia, mantri juga menekankan keberfungisan sosial pada penderita skizofrenia yang ditanganinya. Hal tersebut dilakukan sebagai hal yang diharapkan untuk mampu menjaga keberlanjutan kesembuhan penderita 
skizofrenia setelah dilakukan berbagai metode klinis dalam proses penyembuhannya.

Agar penderita skizofrenia yang ditanganinya tidak kembali kambuh karena keberfungsian sosialnya tidak berkembang optimal, sehingga dalam penanganannya mantri juga mempertimbangkan aspek-aspek keberfungsian sosial seperti yang telah dikatakan oleh Edi Suharto di atas, artinya dalam hal ini keberfungsian sosial oleh mantri telah mampu dipahami dan digunakan sebagai bagian metode yang dianggap penting untuk dilakukan dalam rangkaian proses penyembuhan penderita skizofrenia.

Di sisi lain pendekatan atau metode yang menekankan pada keberfungsian sosial juga merupakan bagian penting dalam praktik pekerjaan sosial, karena bagi pekerja sosial masalah dapat dikatakan tertanggulangi ketika seseorang, komunitas atau masyarakat mampu menjalankan fungsi sosialnya kembali. Berdasar pada fenomena di atas maka rumusan masalah dalam kajian ini adalah "bagaimana metode penyembuhan yang digunakan mantri pada penderita Skizofrenia dalam perspektif pekerjaan sosial?” Adapun tujuan dilaksanakan kajian ini adalah untuk mendeskripsikan, menganalisis metode penyembuhan yang digunakan mantri pada penderita Skizofrenia dalam perspektif pekerjaan sosial.

\section{Metode}

Guna mendapatkan data secara mendalam, dan terperinci secara naturalistik terkait dengan fokus kajian maka penelitian tentang metode penyembuhan yang digunakan mantri pada penderita Skizofrenia dalam perspektif pekerjaan sosial, studi kasus di Dusun Andongsari, Desa Tugusari, menggunakan metode penelitian kualitatif. Pendekatan ini dipandang lebih tepat digunakan untuk mendiskripsikan data-data yang diperlukan oleh peneliti. Jenis penelitian yang digunakan dalam penelitian ini adalah penelitian studi kasus dengan menggunakan pendekatan kualitatif. Dalam hal ini peneliti berusaha untuk memaparkan dan mendeskripsikan penelitian yang diteliti secara sistematis, faktual, dan akurat mengenai fakta-fakta yang ditemukan di lapangan. Penelitian ini mengambil lokasi atau setting penelitian di Desa Tugusari, Kecamatan Bangsalsari, Kabupaten Jember.

Teknik penentuan informan penelitian ini menggunakan purposive. Purposive menurut Sugiyono (2013) adalah penentuan informan dengan pertimbangan tertentu. Ada dua kategori informan yaitu dengan menggunakan informan pokok dan informan tambahan. Teknik dan alat pengumpulan data di lapangan, yaitu teknik observasi ini menggunakan metode observasi partisipasi moderat, teknik wawancara menggunakan 
teknik wawancara semi terstruktur, serta teknik dokumentasi menggunakan pedoman dokumenter berupa foto dan rekaman dengan mantri, keluarga dan lingkungan sekitar penderita skizofrenia.

Teknik analisis data menggunakan beberapa tahapan yaitu mulai dari pengumpulan data mentah, transkrip data, koding, kategorisasi data, penyimpulan sementara, triangulasi dan penyimpulan akhir. Untuk teknik uji keabsahan data menggunakan triangulasi sumber data dan teori.

\section{Hasil dan Diskusi}

Kabupaten Jember masih banyak ditemukan penderita skizofrenia, namun ratarata dari penderita skizofrenia ini kurang mendapatkan perhatian dan penanganan yang baik dari pihak keluarga. Hasil penelitian menunjukkan bahwa di Kabupaten Jember masih banyak fenomena penderita skizofrenia yang kurang mendapatkan perhatian bahkan menjalani pengobatan yang tidak layak. Total penderita skizofrenia yang telah ditangani oleh pemerintah Jember sebanyak 75 orang, rata-rata penderita yang telah ditanganinya semua menjalani pengobatan pemasungan (BD, petugas dinas sosial. September 2016).

Desa Tugusari sendiri dari hasil penelitian terdapat 6 penderita skizofrenia. Dari jumlah tersebut semua penderita dipasung oleh keluarga penderita. Sering munculnya stigma negatif yang diberikan masyarakat tentang skizofrenia menambah keraguan keluarga terhadap kesembuhan penderita skizofrenia, penderita skizofrenia dianggap aneh, tidak waras, berbahaya dan lain-lain. Kebanyakan keluarga menyembunyikan penderita skizofrenia, malu, ada yang dipasung dan bahkan ada juga yang ditelantarkan begitu saja. Belum lagi kepercayaan masyarakat dengan hal mistis yang menganggap penderita skizofrenia disebabkan oleh kerasukan mahkluk gaib dan guna-guna.

Menurut Yosep dan Sutini (2014) Skizofrenia adalah gangguan psikotik menetap di mana orang yang menderitanya memiliki ciri-ciri, seperti kekacauan dalam berpikir, emosi, persepsi, dan perilaku, di mana episode akut dari skizofrenia ditandai dengan waham, halusinasi, pikiran yang tidak logis, pembicaraan yang tidak koheren, dan perilaku yang aneh.

Ironisnya perlakuan keluarga terhadap penderita skizofrenia yang selama ini dilakukan dengan memasung penderita skizofrenia, hal yang dilakukan keluarga penderita tersebut juga dipengaruhi oleh lingkungan sekitar keluarga yang mendukung bahwa penderita skizofrenia sebaiknya dipasung dengan alasan demi faktor keamanan. Pemasungan terjadi karena bermacam-macam alasan, sebagian masyarakat memiliki 
pemahaman dan pengetahuan yang salah tentang gangguan jiwa (skizofrenia).

Penderita skizofrenia dianggap berbahaya bagi lingkungannya, pemasungan dianggap sebagai solusi untuk mengendalikan gejala kerasukan, atau mengurangi ulah penderita skizofrenia. Penderita skizofrenia memiliki tantangan hidup yang begitu sulit ketika harus dihadapkan pada kondisi medis dan sosial secara bersamaan. Hal ini diperburuk oleh reaksi keliru dari masyarakat bahkan keluarga sendiri dengan stigma "orang gila", penolakan terhadap kehadirannya, ditakuti, diskriminasi, bahkan penganiayaan. Sehingga perlu adanya perlakuan yang baik dari keluarga dan lingkungan sekitar agar penderita skizofrenia bisa ditangani.

Menurut Kartono (2002) pada penderita skizofrenia sering dijumpai adanya kendala atau hambatan yang nyata pada taraf kemampuan fungsional sebelumnya dalam bidang pekerjaan, hubungan sosial, kemampuan merawat diri, dan bidang lainnya, yang selanjutnya akan menimbulkan kesulitan dalam kehidupan pribadi, keluarga, maupun kehidupan sosial dari penderitanya. Hal tersebut membuat penderita skizofrenia cenderung menggantungkan sebagian besar aspek kehidupannya pada pihak lain yang peduli terhadapnya, baik itu hubungannya sebagai keluarga atau relasinya.

Penderita skizofrenia yang terdapat di Desa Tugusari yang rata-rata dipasung sedikit terbantu oleh kehadiran seorang mantri desa dalam upaya penyembuhan penderita skizofrenia. Namun dalam upaya yang dilakukan mantri hanya 2 penderita skizofrenia yang dapat diupayakan dalam proses penyembuhannya. Hal initidakterlepas dari stigma masyarakat maupun keluaga penderita tentang penyakit skizofrenia yang dianggap berbahaya dan tidak bisa disembuhkan. Berdasarkan hasil penelitian hanya 2 penderita yang dapat diupayakan oleh mantri dalam proses penyembuhannya, karena dari 6 penderita yang terdapat di Desa Tugusari hanya 2 keluarga penderita yang dapat menerima mantri dalam melakukan upaya penyembuhan penderita skizofrenia.

\section{a. Proses Identifikasi Penderita Skizofrenia}

Upaya pertama yang dilakukan mantri dalam proses penyembuhan penderita skizofrenia adalah melakukan proses identifikasi pada dua penderita skizofrenia. Hal ini dilakukan mantri untuk memberi pengetahuan tentang penyakit skizofrenia agar keluarga dapat memperlakukan penderita skizofrenia dengan baik. Tidak hanya itu dalam proses identifikasi ini mantri juga berupaya untuk mengetahui faktor penyebab skizofrenia dan penentuan tipe skizofrenia yang dialami oleh kedua penderita tersebut. Sehingga mantri dapat menentukan upaya penyembuhan yang tepat bagi kedua 
penderita skizofrenia tersebut.

\section{Faktor Penyebab Skizofrenia}

Dalam proses identifikasi yang dilakukan mantri lebih kepada pendekatan dengan keluarga untuk memperoleh informasi atau data tentang penyebab penderita mengalami skizofrenia. Dalam hal ini mantri memandang faktor penyebab skizofrenia lebih kepada masalah internal yang dialami kedua penderita, seperti penderita memiliki pribadi yang mudah tersinggung, trauma, tidak bisa menyelesaikan masalah, dan faktor keturunan. Penyebab skizofrenia juga gangguan sosial atau lingkungan. Penyebabnya dapat berupa stressor psikososial perkawinan, problem orang tua, hubungan antar personal dalam pekerjaan atau sekolah, di lingkungan hidup, dalam masalah keuangan, hukum, perkembangan diri, faktor keluarga, penyakit fisik, dan lain-lain.

\section{Penentuan Tipe Skizofrenia}

Berdasarkan hasil penelitian dengan gejala yang sama dialami oleh kedua penderita tersebut, mantri mendiagnosis 2 penderita tersebut menderita skizofrenia dengan tipe paranoid. Hal ini senada dengan Kartono (2003) bahwa skizofrenia tipe paranoid adalah tipe yang paling sering dijumpai. Gejala utama dari tipe ini adalah halusinasi dan waham (keyakinan atau pikiran) yang sangat dominan. Waham bisa lebih dari satu, misalnya pasien merasa dirinya dimatai-matai, sekaligus merasa sebagai orang penting dan berkuasa. Halusinasi bisa terkait dengan wahamnya, misalnya penderita mendengar suara-suara yang mengatakan bahwa ia harus hati-hati karena ada yang berniat membunuhnya. Pada tipe ini jarang dijumpai adanya pikiran yang kacau atau emosi yang mendatar.

\section{b. Metode Penanganan dalam Proses Penyembuhan Penderita Skizofrenia}

Sebelum mantri melakukan upaya penyembuhan penderita skizofrenia yang dilakukan ialah pendekatan dengan keluarga dengan tujuan memberikan pengetahuan tentang penyakit skizofrenia dan mantri memberi motivasi keluarga serta memberikan solusi penanganan yang tepat untuk penderita skizofrenia. Amador 1994 (Gerald et.al., 2006) menyatakan bahwa suatu masalah besar dalam jenis penanganan apa pun untuk skizofrenia adalah banyak pasien yang menderita skizofrenia kurang memiliki insight atas hendaknya mereka dan menolak semua terapi yang diberikan. Karena keluarga 
tidak percaya bahwa mereka menderita suatu penyakit, keluarga tidak merasa membutuhkan intervensi profesional, terutama bila mencakup perawatan di rumah sakit atau pemberian obat-obatan.

Berdasarkan hasil penelitian mantri dan petugas dinas sosial berupaya untuk memberikan pengetahuan tentang penyakit skizofrenia dan bagaimana penanganan yang seharusnya diberikan. Tidak hanya itu mantri dan petugas dinas sosial juga merujuk kedua penderita tersebut ke rumah sakit untuk direhabilitasi. Dalam upaya penanganan ini ada dua upaya yakni pengobatan dan upaya pengembalian keberfungsian sosial penderita skizofrenia.

\section{Pengobatan Penderita Skizofrenia}

Metode penanganan pertama yang dilakukan oleh mantri ialah dengan cara pengobatan secara medis dengan memberikan suntikan dan obat penenang. Menurut Kopelowicz, Liberman, dan Zarate (Gerald et.al., 2006) obat-obatan secara kolektif disebut obat-obatan antipsikotik, yang juga disebut neuroleptik karena menimbulkan efek samping yang sama dengan simtom-simtom penyakit neurologis. Obat tersebut dalam penanganan eksperimental mampu mengurangi tingkat kekambuhan hingga setengahnya dan mengurangi tingkat perawatan kembali di rumah sakit.

\section{Pengembalian Keberfungsian Sosial Skizofrenia}

Berdasarkan hasil penelitian setelah mantri melakukan pengobatan secara medis pada penderita skizofrenia, mantri melakukan upaya penyembuhan penderita skizofrenia melalui metode pengembalian keberfungsian sosial. Bentuk metode ini adalah terapi pada keluarga untuk pengenalan skizofrenia dan menggali potensi yang dimiliki penderita. Tahapan-tahapan dalam metode pengembalian keberfungsian sosial ini di lakukan sebagai berikut.

\section{a. Memahamkan Keluarga tentang Disabilitas Kognitif}

Melaui tahapan kegiatan terapi ini penderita skizofrenia dan keluarganya dipahamkan bahwa disabilitas kognitif yang menjadi salah satu ciri skizofrenia dapat membatasi sejauh mana penderita penyakit ini dapat memperoleh manfaat dari berbagai penanganan psikologis. Penanganan psikososial sama menjanjikannya seperti banyak obat antipsikotik terbaru, suatu pengabaian terhadap aspek psikologis dan sosial dalam skizofrenia mengurangi arti berbagai upaya yang dilakukan untuk menangani penderita skizofrenia dan keluarganya (Bowen 1944 dalam Gerald et.al., 
2006). Dalam tahap ini mantri berupaya mencegah perlakuan disabilitas kognitif keluarga terhadap pasien yang selama ini diberikan kepada penderita skizofrenia. Sebab perlakuan semacam ini yang diberikan keluarga juga akan berdampak pada kesembuhan penderita skizofrenia. Huda (2009) melakukan terapi keluarga sama pentingnya dengan melakukan terapi terhadap individu maupun masyarakat secara luas. Melakukan terapi terhadap keluarga secara tidak langsung juga dapat menyembuhkan individu.

\section{b. Pengenalan Skizofrenia pada Lingkungan}

Berdasarkan hasil penelitian mantri berupaya melakukan pendekatan kepada beberapa tetangga sekitar penderita yang bertujuan untuk mengurangi stigma negatif, perlakuan yang selama ini diberikan oleh lingkungan sekitar. Weissmas 1998 dan Lopez 1999 (Gerald et.al., 2006) mengindikasikan bahwa lingkungan keluarga dalam menjalani proses penyembuhan penderita sangat berpengaruh seberapa cepat penderita dapat kambuh kembali. Sering terjadi bahwa simtom-simtom negatif skizofrenia paling mungkin menimbulkan kritik, dan para kerabat dari penderita membuat keluarga harus membatasi ruang geraknya dan berbagai upaya lain dapat meningkatkan kadar ekspresi emosi.

\section{c. Menggali Potensi yang Dimiliki PenderitaSkizofrenia}

Mantri juga berupaya melakukan terapi individu yang bertujuan untuk mengembalikan penderita skizofrenia supaya mampu menjalankan perannya, kembali beraktifitas atau bekerja sesuai dengan potensi yang dimiliki oleh kedua penderita tersebut. Disebut sebagai client-centered terapy (terapi berpusat pada klien). Rogers 1965 (Huda, 2009) mengatakan bahwa setiap orang pada dasarnya mempunyai motif aktualisasi diri (self-actualization motive). Motif aktualisasi diri ini melekat pada setiap diri seseorang sehingga tenaga ahli dapat menjaga maupun meningkatkan motif tersebut. Pada dasarnya manusia mempunyai potensi untuk dapat berbuat baik dan menjadi lebih bermoral dalam kehidupan masyarakat.

\section{Diskusi}

Berdasarkan hasil penelitian tentang metode penyembuhan yang digunakan mantri pada penderita skizofrenia dalam perspektif pekerjaan sosial, keberadaan seorang mantri telah membantu keluarga dan penderita skizofrenia untuk sembuh. Namun dalam proses penyembuhannya ada beberapa metode yang kurang sesuai, 
seperti ketika mantri melakukan proses identifikasi terhadap penderita skizofrenia dalam hal ini mantri melakukan proses identifikasi dengan cara melakukan pendekatan terhadap keluarga saja untuk memperoleh informasi atau data tentang penyakit skizofrenia yang diderita oleh anggota keluarganya. Dalam proses identifikasi tentang penderita skizofrenia seharusnya dilakukan secara menyeluruh untuk memperoleh informasi yang akurat sehingga penanganan yang diberikan mantri sesuai dengan penderita skizofrenia.

Hepworth dan Larsen (Huda (2009) mengatakan assessment adalah suatu proses mengumpulkan, menganalisis dan menyintesiskan data-data penting ke dalam bentuk yang meliputi dimensi-dimensi berikut ini: (1) sifat dasar masalah klien, meliputi perhatian khusus kepada kebutuhan perkembangan dan penekanan ditujukan kepada transisi kehidupan yang membutuhkan adaptasi yang utama, (2) meningkatkan kapasitas klien dan pihak lain yang signifikan (biasanya anggota keluarga) meliputi kekuatan, keterampilan, aset pribadi, keterbatasan dan kekurangan, (3) sistem yang relevan meliputi masalah klien dan transaksi timbal balik antara klien dan sistemnya, (4) sumber yang didapat atau dibutuhkan untuk pengobatan atau mengurangi masalah, dan (5) motivasi klien untuk mengatasi masalahnya.

Begitu juga ketika mantri dalam mengidentifikasi faktor penyebab skizofrenia mantri menganggap faktor penyebab skizofrenia disebabkan oleh faktor internal. Dalam perspektif kesejahteraan sosial dalam memandang faktor penyebab yang dialami oleh seseorang, tidak hanya dilihat dari faktor internal saja tapi faktor eksternal juga dapat berpengaruh pada masalah yang dialami klien. Huda (2009) dalam memandang klien, bahwa klien dipandang sebagai mahluk yang memiliki potensi dan kekuatan sehingga potensi dan kekuatan tersebut dapat dijadikan modal penting dalam proses perubahan yang ada pada diri seseorang.

Dalam penentuan tipe skizofrenia mantri telah melakukan tugasnya sebagai seorang ahli medis. Dalam penentuan tipe skizofrenia ini mantri mendiagnosis kedua penderita mengalami skizofrenia dengan tipe paranoid. Kartono (2003) menyebut skizofrenia tipe paranoid adalah tipe yang paling sering dijumpai. Gejala utama dari tipe ini adalah halusinasi dan waham (keyakinan atau pikiran) yang sangat dominan. Waham bisa lebih dari satu, misalnya pasien merasa dirinya dimatai-matai, sekaligus merasa sebagai orang penting dan berkuasa. Halusinasi bisa terkait dengan wahamnya, misalnya penderita mendengar suara-suara yang mengatakan bahwa ia harus hati-hati karena ada yang berniat membunuhnya. Pada tipe ini jarang dijumpai adanya pikiran yang kacau atau emosi yang mendatar. 
Begitu juga ketika mantri melakukan upaya pengobatan mantri telah melakukan tugasnya sebagai seorang ahli medis, dengan cara memberikan obat dan suntukan kepada kedua penderita skizofrenia. Namun pengobatan yang diberikan oleh mantri kepada penderita skizofrenia sifatnya hanya sementara, karena pengobatan yang diberikan hanya mengurangi tingkat emosi yang dialami penderita. Mantri menganggap perlu adanya penanganan atau terapi yang lebih tepat lagi demi kesembuhan penderita skizofrenia. Dalam hal ini mantri berupaya mengembalikan keberfungsian sosial penderita skizofrenia.

Upaya mantri dalam pengembalian keberfungsian sosial penderita skizofrenia ini melengkapi terapi medis karena penyebab skizofrenia di samping faktor internal dan biologis juga faktor eksternal. Penanganan faktor eksternal dilakukan melalui tahap pengembalian keberfungsian sosial penderita skizofrenia. Terapi ini dilakukan dengan cara mantri melakukan terapi pada keluarga dan terapi lingkungan penderita skizofrenia.

Menurut Huda (2009) melakukan terapi keluarga sama pentingnya dengan melakukan terapi terhadap individu maupun masyarakat secara luas. Melakukan terapi terhadap keluarga secara tidak langsung juga dapat menyembuhkan individu. Dengan demikian dapat dipahami bahwa keluarga juga sangat berpengaruh terhadap perlakuan yang diberikan terhadap penderita skizofrenia akan berdampak juga pada kesembuhan penderita skizofrenia. Menurut Prayitno (2011), salah satu keterampilan dan keahlian lain dari seorang pekerja sosial medis adalah melakukan terapi keluarga. Dukungan keluarga atau sahabat melalui kehadiran mereka entah sebagai teman bicara atau melakukan aktivitas yang pasien inginkan akan sangat berguna untuk percepatan kesembuhan pasien. Selain itu dukungan keluarga atau sahabat agar pasien tetap menjalani program pengobatan yang dianjurkan dokter.

Mantrijuga melakukan pendekatan padalingkungan sekitar penderita skizofrenia, dalam hal ini mantri berupaya memberikan pengetahuan tentang penyakit skizofrenia pada beberapa tetangga terdekat penderita dengan tujuan untuk mengurangi stigma negatif yang diberikan oleh masyarakat terhadap penderita skizofrenia dan supaya lingkungan sekitar dapat menerima serta memperlakukan penderita skizofrenia dengan baik. Huda (2009) menyebut pendekatan kelompok sebagai sarana penyembuhan, kelompok dapat membantu proses penyembuhan klien.

Mantri juga berupaya melakukan terapi individu dan menggali potensi yang dimiliki kedua penderita skizofrenia yang bertujuan untuk mengembalikan keberfungsian sosial penderita skizofrenia. Client-centered terapy (terapi berpusat 
pada kilien) menurut Rogers 1965 (Huda 2009) bahwa setiap orang pada dasarnya mempunyai motif aktualisasi diri (self-actualization motive). Motif aktualisasi diri ini melekat pada setiap diri seseorang sehingga tenaga ahli dapat menjaga maupun meningkatkan motif tersebut. Pada dasarnya manusia mempunyai potensi untuk dapat berbuat baik dan menjadi lebih bermoral dalam kehidupan masyarakat. Melalui terapi keberfungsian sosial diupayakan untuk meningkatkan kemampuan orang (individu, keluarga, kelompok atau masyarakat) dan sistem sosial (lembaga, dan jaringan sosial) dalam memenuhi atau merespon kebutuhan dasar, menjalankan peranan sosial, serta menghadapi goncangan dan tekanan (shocks and stresses).

Upaya yang diberikan mantri selama ini sudah dapat membantu baik itu bagi penderita dan keluarga, secara tidak langsung keluarga terbantu dengan adanya upaya mantri dalam proses penyembuhan penderita skizofrenia. Apa yang dilakukan oleh Mantri bisa digunakan sebagai referensi pekerja sosial medis (PSM) dapat bertindak sebagai fasilitator, sehingga banyak hal yang bisa difasilitasi oleh seorang pekerja sosial medis (PSM) dalam kaitannya dengan kepentingan pasien maupun RS, di antaranya memfasilitasi pasien yang mengalami kendala dengan keuangan, memfasilitasi konflik yang terjadi antara pihak rumah sakit dengan pihak luar, memfasilitasi proses pelayanan konseling pada pasien. Prinsipnya adalah seorang pekerja sosial medis memang telah dididik untuk mempunyai kemampuan sebagai fasilitator yang bisa menfasilitasi kaitannya antar pasien dengan rumah sakit ataupun antara pasien dengan pihak luar yang secara tidak langsung bisa mempengaruhi proses pelayanan.

\section{Penutup}

Kehadiran seorang mantri mampu membantu meringankan baik itu keluarga dan penderita skizofrenia itu sendiri, sebab selama ini pengobatan yang diberikan oleh keluarga pada penderita skizofrenia dengan berobat alternatif, dan belum lagi faktor ekonomi keluarga yang membuat keluarga enggan membawa penderita skizofrenia untuk berobat. Sehingga dengan adanya mantri telah membantu keluarga penderita dalam upaya penyembuhan penderita skizofrenia. Metode penyembuhan yang dilakukan mantri terhadap penderita skizofrenia dilakukan melalui terapi medis dengan cara memberikan obat-obatan medis, dan melalui terapi untuk berupaya mengembalikan keberfungsian sosial penderita skizofrenia tersebut.

Tahapan terapi keberfungsian sosial dilakukan melalui serangkaian kegiatan (a) memahamkan keluarga tentang disabilitas kognitif; (b) pengenalan skizofrenia pada lingkungan; (c) menggali potensi yang dimiliki penderita skizofrenia. Dalam proses 
penyembuhan mantri melakukan pendekatan terhadap keluarga dan lingkungan penderita sebagai dukungan untuk membantu proses penyembuhan penderita skizofrenia. Mantri tidak hanya melakukan upaya proses penyembuhan penderita skizofrenia saja namun mantri juga berupaya mengembalikan keberfungsian sosial penderita skizofrenia. Metode penyembuhan yang dilakukan mantri terhadap penderita skizofrenia tersebut bisa digunakan referensi oleh Pekerja Sosial Medis dalam menangani klien dengan masalah yang sama, sekaligus bekerja sama dengan para matri yang berpengalaman menangani penderita skizofrenia.

\section{Daftar Pustaka}

Davison, Gerald C., Neale. Jhon M., dan Kring. Ann. M. (2006). Psikologi Abnormal. Jakarta: PT. Raja Grafindo Persada.

Fausiah, F. \& Widury. (2006). Psikologi Abnormal Klinis Dewasa. Jakarta: Universitas Indonesia.

Huda, Miftachul. (2009). Pekerjaan Sosial \& Kesejahteraan Sosial. Yogyakarta: Pustaka Pelajar.

Kartono, K. (2003). Patologi Sosial Gangguan-Gangguan Kejiwaan. Jakarta: Raja Grafindo Persada.

Suharto, E. (2009). Membangun Masyarakat Memberdayakan Rakyat (Kajian Strategis Pembangunan Kesejahteraan Sosial dan Pekerjaan Sosial). Bandung: Refika Aditama. Sugiyono. (2009). Memahami penelitian Kualitatif: Dilengkapi Contoh Proposaldan Laporan Penelitian. Bandung: Alfabeta.

Yosep, I. \& Sutini, T. (2014). Buku Ajar Keperawatan Jiwa. Bandung: Refika Aditama. Undang-undang Republik Indonesia Nomor 36 Tahun 1980 tentang Usaha Kesejahteraan Sosial bagi Penderita Cacat Undang-undang Nomor 39 Tahun1999 tentang Hak Asasi Manusia Prayitno, H. (2011). Model Kompetensi Pekerja Sosial Medis Di Rumah Sakit Sebagai Upaya Peningkatan Kualitas Pelayanan Kesehatan. Laporan Hasil Penelitian Hibah Bersaing, Lembaga Penelitian Universitas Jember. Diakses dari http://repository. unej.ac.id/handle/123456789/5671 